\title{
OPEN
}

\section{Publisher Correction: Metabolic phenotype of breast-fed infants, and infants fed standard formula or bovine MFGM supplemented formula: a randomized controlled trial}

\author{
Xuan $\mathrm{He}^{1,2}$, Mariana Parenti ${ }^{1}$, Tove Grip ${ }^{3}$, Magnus Domellöf ${ }^{3}$, Bo Lönnerdal ${ }^{1}$, Olle Hernell ${ }^{3}$, \\ Niklas Timby ${ }^{3}$ \& Carolyn M. Slupsky ${ }^{1,2}$
}

Correction to: Scientific Reports https://doi.org/10.1038/s41598-018-36292-5, published online 23 January 2019

In the original version of this Article, the author Carolyn M. Slupsky was incorrectly indexed. This error has now been corrected.

\begin{abstract}
(c) (i) Open Access This article is licensed under a Creative Commons Attribution 4.0 International Ly License, which permits use, sharing, adaptation, distribution and reproduction in any medium or format, as long as you give appropriate credit to the original author(s) and the source, provide a link to the Creative Commons license, and indicate if changes were made. The images or other third party material in this article are included in the article's Creative Commons license, unless indicated otherwise in a credit line to the material. If material is not included in the article's Creative Commons license and your intended use is not permitted by statutory regulation or exceeds the permitted use, you will need to obtain permission directly from the copyright holder. To view a copy of this license, visit http://creativecommons.org/licenses/by/4.0/.
\end{abstract}

(C) The Author(s) 2019

\footnotetext{
${ }^{1}$ Department of Nutrition, University of California Davis, One Shields Ave, Davis, CA, 95616, USA. ${ }^{2}$ Department of Food Science and Technology, University of California Davis, One Shields Ave, Davis, CA, 95616, USA. ${ }^{3}$ Department of Clinical Sciences, Pediatrics, SE 90185 Umeå University, Umeå, Sweden. Correspondence and requests for materials should be addressed to C.M.S. (email: cslupsky@ucdavis.edu)
} 